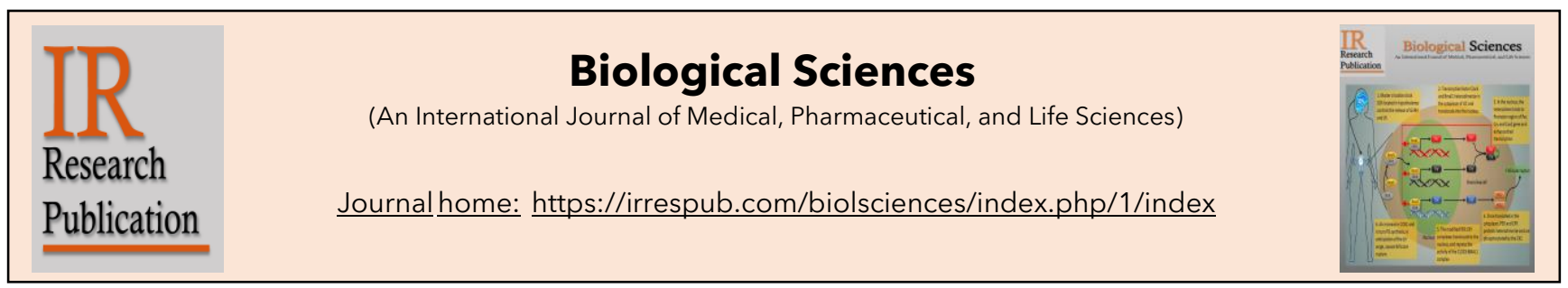

\title{
An update on COVID-19 outbreak: The longest pandemic
}

\author{
Seema Mahor ${ }^{1}$, Hina Chadha ${ }^{1}$, Sarita Prajapati², Sudhanshu Mishra ${ }^{3}$, Smriti Ojha ${ }^{3 *}$ \\ ${ }^{1}$ Department of Pharmaceutical Sciences, Vishveshwarya Group of Institutions, Greater Noida, Uttar Pradesh. \\ ${ }^{2}$ United College of Engineering and Research, Greater Noida, Uttar Pradesh. \\ ${ }^{3}$ Department of Pharmaceutical Science \& Technology, Madan Mohan Malaviya University of Technology, Gorakhpur, \\ Uttar Pradesh.
}

\section{ARTICLE HISTORY}

Received: 17-01-2022

Revised: 26-01-2022

Accepted: 28-01-2022

Online: 31-01-2022

\section{KEYWORDS}

Coronavirus

Pandemic

Immune System

Respiratory disease

Multiorgan failure

\section{ABSTRACT}

A novel epidemic case of coronavirus disease is an infectious disease caused by a newly discovered virus COVID-19, they are originated by some untraceable origin. Coronavirus belongs to a large family of viruses that may cause illness in animals or humans. They are known to cause respiratory infections starting from the common cold to more severe diseases such as Severe Acute Respiratory Syndrome (SARS). The first transmission of the Corona virus was seen to humans in Wuhan, China. Since then, these viruses have mostly spread almost all over the world through person-to-person contact and mainly expanding in Europe, North America, Asia, and also in India. The irony is not much is known about this virus, hence mortality and morbidity across the globe are at a peak. The Ministry of Health and Family Welfare, Government of India, and Indian Council of Medical Research (ICMR) have formulated some guidelines, advisories for social distancing protocol, diagnosis, management, do's and don'ts, and other reliable material to break the chain of this viruses. The current article covers the introduction, history and background, origin and spread, possible mode of transmission, clinical features, symptoms, diagnosis and testing, treatment and management, role of antiviral and preventive measurement from COVID-19. This article may help readers to have the latest understanding of this new infectious disease.
*Address for correspondence

Department of Pharmaceutical Sciences and Technology, Madan Mohan Malaviya University of Technology, Gorakhpur, Uttar Pradesh, India.

Email: smritiojha23@gmail.com

DOI: http://dx.doi.org/10.55006/biolsciences.2022.2102 Published by IR Research Publication; Mahor S et al (C) 2022 by Biological Sciences is licensed under CC BY 4.0 (C)

\section{Introduction}

The Novel Corona Virus (COVID-19) earlier known only as the Wuhan virus, started to expand from Wuhan City of Hubei Province of China since December 2020 to neighbour countries like Japan, South Korea, Italy, Iran and India [1]. This virus has been given a name novel because it is never seen before. As till now, a certain source of the outbreak is unknown, but it is believed that the virus might be linked with a wet market with seafood and live anim- 
-als from Wuhan that were not complying with health and safety regulations. The symptomatology of COVID-19 is very similar to other viral respiratory infections. Cases are very mild forms to severe ones that can lead to serious health conditions or even death. It is also believed that symptoms may appear in 2 to 14 days, as the incubation period for the novel coronavirus has not yet been confirmed. Many researchers said that it is originally emerged as an animal source but now spreading from person to person by contact. There has been a supposition about the virus spreading while the carrier (infected person) is not showing any symptoms, but that has not been confirmed as a scientific fact. Symptoms that may arise as a result of being infected are septic shock, pneumonia, and ARDS (Acute Respiratory Distress Syndrome) [2]. Initial cases of this virus were reported in December 2019 [3]. Later, on 7th January 2020, Chinese health authorities also confirmed that this was due to a novel coronavirus COVID-19 [4]. On 30th January 2020, around 9976 cases were detected in at least 21 countries [5]. Furthermore, cases were increased, involving the whole of China and 27 other countries up to 70,000 on Feb 17, 2020 [6]. On the basis of alarming levels of spreading and severity and by the alarming levels of inaction on 11th March 2020, the DirectorGeneral of WHO characterized the COVID-19 disease as a pandemic [7].

A generic report published by the Chinese Centre for Disease Control and Prevention (CCDP) on the epidemiological characteristics of 72314 patients infected with COVID-19 confirmed the previous understanding that most known infections cause mild disease, with a case fatality ratio that ranged from $2.9 \%$ in Hubei province to $0.4 \%$ in the other Chinese provinces [8]. This Chinese report also suggested that elderly people, especially those more than 80 years, and people with comorbidities like diabetes, cardiac disease, and respiratory disease are at higher risk of serious mode and death. The case definition of disease used in China changed many times as COVID-19 progressed, making it very difficult to completely characterize its natural history of infection, including the mortality ratio [9].

\section{History and background}

In the year of December 2019, a new virus surfaced in Wuhan, Hubei Province, the People's Republic of China, called COVID-19 [10]. These viruses are identified as positive-sense RNA viruses whose size range is from $60 \mathrm{~nm}$ to $140 \mathrm{~nm}$ in diameter with spike-like projections on its surface, which gives it a crown-like structure that was seen under the electron microscope, hence the name adopted as coronavirus [11]. It started spreading rapidly across China and nearby countries including India. Initial cases of this disease were reported in December 2019 in China [12]. In the past two decades, there have been two events wherein the crossover of some animal beta coronaviruses transferred to humans has resulted in severe disease. The first case was in the year 2002 to 2003 when a new coronavirus of the $\beta$ genus with origin in bats crossed over to humans by an intermediary host of palm civet cats in the Guangdong province of China. At that time, this virus was named severe acute respiratory syndrome (SARS).

Coronavirus affected approximately 8422 people, mostly in China and Hong Kong, which caused 916 deaths (mortality rate around $11 \%$ ) before being contained [13]. World Health Organization has named this disease as COVID-19 officially. ICTV International Committee on Taxonomy of Viruses named this virus severe acute respiratory syndrome coronavirus 2 (SARS-CoV-2). In the year of 2012, a new disease has generated from bats with dromedary camels as the intermediate host, named as Middle East Respiratory Syndrome Coronavirus (MERS-CoV) in Saudi Arabia. This disease affected around 2494 people of which 858 deaths were reported (fatality rate around 34\%) [14]. According to researchers, four viruses from the corona family have already been discovered, named as HKU1, 229E, NL63, and OC43, they spread infection in humans and cause mild respiratory disease. Symptoms of this disease are very similar to pneumonia a viral disease. The researchers of the Centers for Disease Control (CDC) declared this disease as pneumonia after complete analysis on respiratory samples, but later this disease is known as novel coronavirus pneumonia (NCP) as it was caused by a new coronavirus [15]. This virus belongs to $\beta$-coronavirus, a large class of viruses that is prevalent in nature. SARS-CoV-2 has a big class of natural hosts, intermediate hosts, as well as final hosts in the same manner as other viruses. This virus has a high transmissibility and infectivity rate despite low mortality [16].

\section{Origin and spread}

In December 2019, people in Wuhan, China, identified an outbreak attack of a virus and started observing symptoms of severe pneumonia of unknown cause, many of the infected persons had a common exposure to the Huanan wholesale seafood market as they were engaged in the trading of live animals. The surveillance system was activated and samples of infected patients from the respiratory system were sent to specific laboratories for diagnosis purposes. On December 31st, 2019, China was informed about the signals of the outbreak of Covid-19 to the World Health Organization, and on the 1st week of January, the Huanan seafood market was strictly ordered to be 
closed. On 7th January 2020, the virus was finally recognized as a coronavirus that had around 95\% similarity with the bat coronavirus and more than $70 \%$ homology with the SARS-CoV. Various environmental samples also had taken and tested from the Huanan seafood market also observed positive, this test confirms that the virus was initiated from there only. It was also observed that the number of infections started increasing very rapidly and the shocking news is that some of the cases did not have any kind of exposure to the live animal market, this message indicated that transmission of the virus was done due to the close contact of human to human. If we talk about fatal cases it was observed that the first fatal cases of Covid-19 were reported on 11th Jan 2020 in China. Suddenly, these cases were also reported from other parts of China and various nearby countries such as Japan, Thailand, and South Korea in a very short time. Transmission of the virus was also observed in those healthcare workers that were engaged in caring for the infected patients. In Wuhan, about 11 million people were placed under lock-down conditions and with special restrictions of entry and exit of anyone from home as well as outer regions. Many other cases of COVID- 19 infection in neighborhood countries of China were also reported with no history of travel to China, it was indicated that the virus was communicated from person to person. This viral infection could also be transmitted from an asymptomatic person to other healthy people before the onset of symptoms. Various countries, including India, decided to evacuate their citizens from China as soon as possible through special transport and placed all these people in isolation for 14 days after that sent them for testing of viral infection. The rate of infection continued to increase very rapidly in China and total cases were reported approximately 15,000 within 24 hours on 12th February 2020, and these scenarios continued to become around 80.000 on 5th March 2020, in China and 87 other countries and around 96,000 cases worldwide. Only 3 cases had been reported in India till 2nd March 2020, but the sudden increase of infection has also been seen by 5th March 2020. In India, infection is mainly reported in Delhi, Agra, and Jaipur which has around 29 infected people due to the contact of Italian tourists. Recently, it is observed that the number of infections of Covid-19 has reduced in China lately, but it is increasing rapidly in other neighborhood countries including India, Italy, South Korea, and Iran. Of those infected people, approximately $20 \%$ are in a very critical condition, $25 \%$ of cases have recovered, and 3310 have died [17].

\section{Different variants of SARS CoV-2}

Variant of interest (VOI)
If a variant has mutations that are believed or known to cause major alterations and is widely distributed, it is termed a variant of interest (e.g., known to cause many clusters of infected people, or found in many countries) [18]. Many variants of interest are being monitored by $\mathrm{WHO}$ in case they develop into variants of concern. Variants with specific genetic markers have been linked to changes that may result in increased transmissibility or virulence, decreased neutralization by antibodies obtained through natural infection or vaccination, the ability to evade detection, or a decrease in therapeutic or vaccination effectiveness. Since the start of the pandemic, the WHO has identified eight variants of interest: Epsilon (B.1.427 and B.1.429), Zeta (P.2), Eta (B.1.525), Theta (P.3), lota (B.1.526), Kappa (B.1.617.1), Lambda (C.37), and Mu (B.1.621) [19, 20].

\section{Variant of concern (VOC)}

If a variant of interest is known to spread more easily, produce more severe disease, evade the immune system, modify the clinical presentation, or reduce the effectiveness of established instruments - such as public health initiatives, diagnostics, therapies, and vaccines - it becomes a variant of concern [21]. The Alpha form (B.1.1.7) is a dangerous SARS-CoV2 variant. It's thought to be $40-80$ percent more transmissible than SARS-CoV-2 in its wild form (with most estimates occupying the middle to the higher end of this range). It was initially discovered in November 2020 in a sample taken in September in the United Kingdom, and by mid-December, it had spread rapidly, coinciding with an increase in infection rates. One or more mutations in the virus' spike protein are suspected to be responsible for at least some of the rise [22]. Tegally et al. discovered a new SARS-CoV-2 lineage B.1.351, also known as Beta variation or GH501Y.V2, with numerous spike mutations in October 2020, resulting in the second wave of COVID-19 infections in Nelson Mandela Bay, South Africa. The B.1.351 variant contains nine mutations in the spike protein (L18F, D80A, D215G, R246I, K417N, E484K, N501Y, D614G, and A701V), three of which are located in the RBD and increase the binding affinity for the ACE receptors. At the end of January 2021, SARS-CoV-2 501Y.V2(B.1.351 lineage) was reported in the United States. This variant has a higher risk of transmission and is less resistant to monoclonal antibody therapy, convalescent sera, and post-vaccination sera [23, 24]. The P.1 variation, also known as Gamma variant or GR/501Y.V3, was discovered in Brazil in December 2020 and was first detected in the United States in January 2021. The spike protein in the B.1.1.28 variant has ten mutations (L18F, T20N, P26S, D138Y, R190S, H655Y, T1027I V1176, K417T, E484K, and N501Y). The RBD contains three alterations (L18F, K417N, and E484K), which are 
similar to the B.1.351 variation. This variety has spread to 45 countries, according to a WHO epidemiological bulletin from March 30, 2021. Importantly, monoclonal antibody treatments, convalescent sera, and post-vaccination sera may be less neutralized by this type[25]. The fourth variety of concern, B.1.617.2 (also known as the Delta variant), was first found in India in December 2020 and was responsible for the deadly second wave of COVID-19 infections in India in April 2021. This variation was first found in the United States in March 2021, and it is now the most common SARSCoV-2 strain in the country. Initially, the Delta variant was thought to be a variant of interest. However, due to its rapid spread over the world, the WHO classified this strain as a VOC in May 2021. The B.1.617 is an abbreviated version of the B.1.617 [26]. After an increase in the number of cases of COVID-19, the fifth variant of concern B.1.1.529, also known as the Omicron variant by the $\mathrm{WHO}$, was first found in South Africa on November 23, 2021. Omicron was rapidly identified as a VOC because of over 30 mutations in the virus's spike protein, as well as a dramatic increase in the number of cases reported in South Africa. T91 in the envelope, P13L in the nucleocapsid protein, E31del, R32del, S33del, R203K, G204R in the nucleocapsid protein, D3G, Q19E, A63T in the matrix, N211del/L212I, Y145del, Y144del, Y143del, G142D, T95I, V70del, H69del, In the receptor-binding domain of the spike, Y505H, N501Y, Q498R, G496S, Q493R, E484A，T478K，S477N， G446S，N440K，K417N, S375F, S373P, S371L, G339D, D796Y in the fusion peptide of the spike, L981F, N969K, Q954H. The Spike mutation K417N (also observed in the Beta version) in combination with $\mathrm{E} 484 \mathrm{~A}$ is projected to have a disproportionately disruptive effect, rendering Omicron more likely to have vaccination breakthroughs [27].

\section{Transmission}

One of the most common modes of infection of Covid-19 is through small droplets from the mouth and nose of the infected person when they cough or exhaled in front of a healthy one. These small droplets affect other things when they land on various surfaces like floors, objects, and clothes, and when some other healthy people touch these things and then touch their nose, eyes, or mouth, they also get infected. Only a single infected person is sufficient to spread the virus to two or more than two people. As the number of cases increases, the chances of infections also increase, because the infection is totally spread from human to human. It is also observed that the infection is only spread through mammals and birds. This virus is very much resistant to staying on the surface of objects for days and remains in the air for many hours. Researchers also indicated that the infection can also spread through the ocular medium [28] From the previous report, it has proved that there are three situations in which the virus can spread [29].

- In aspects of the source of infection

- In aspects of the route of transmission

- In aspects of the Susceptibility

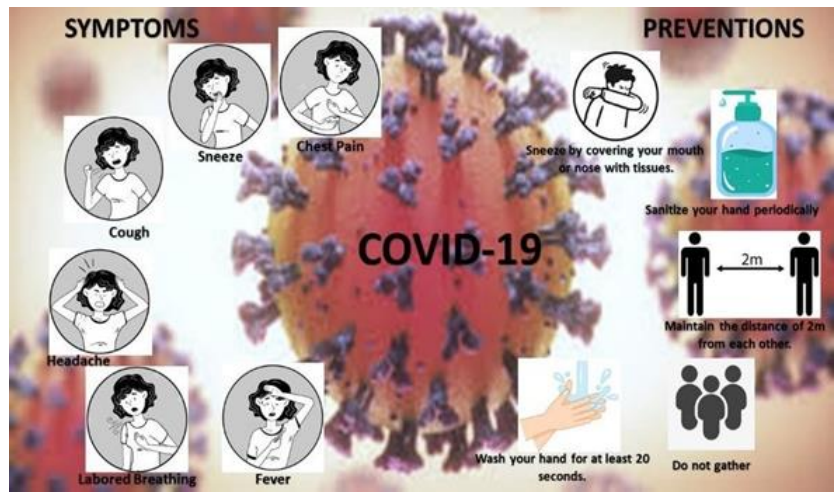

Figure 1. The symptoms and prevention from COVID-19.

\section{In aspects of the source of infection}

From the studies done at the Institute Pasteur of Shanghai, we reported that bats are one of the most important causes of the spread and natural hosts of this virus, while snakes or pangolins are said to be the intermediate hosts. Another study also done by Peking University reported snakes are responsible for this disease [30]. However, according to further study, no evidence was found in which it is reported that snakes are responsible for such infections. Although it is still not clear about the natural host and intermediate host of the virus, but some study has proved that this infection might be sourced from wild animals. Currently, it is also considered that the main source of infection of this disease is COVID-19 patients [31].

\section{In aspects of the route of transmission}

The most common mode of spreading of the virus is aerosol transmission and close contact with other individuals as many researchers have detected this virus in samples of the gastrointestinal tract, stool, urine, and saliva. It is also observed by some researchers that the digestive tract can also be a route of Covid-19 infection [32]. Furthermore, the cause of infection was also detected in tears, conjunctive secretion, and gastrointestinal tissues of COVID-19 patients [33].

In aspects of susceptibility

From various epidemiological studies, it is clear that older people are much more susceptible for 


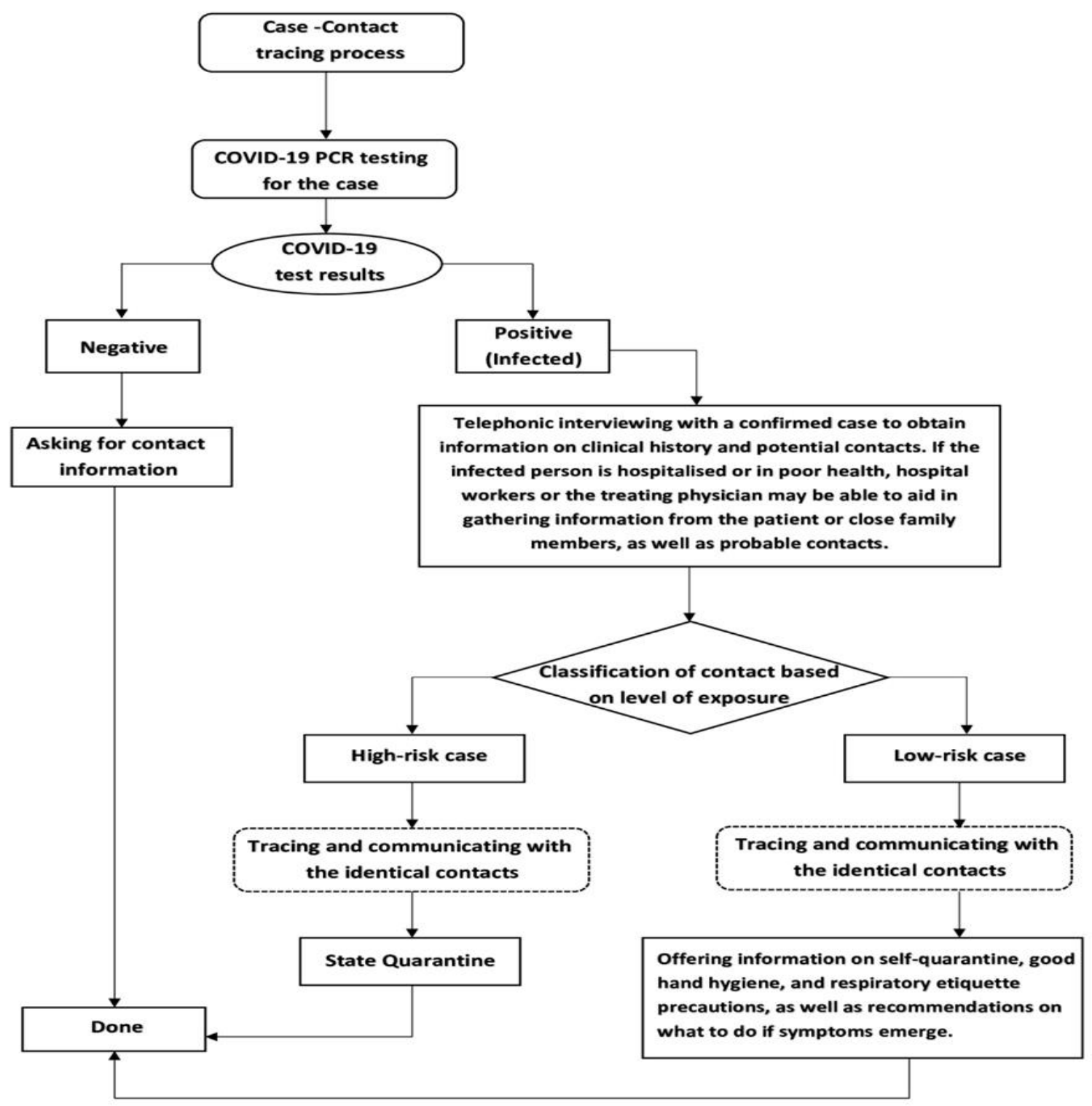

Figure 2. Common protocol for suspected cases of n-COVID 19.

catching the infection, the median age of death was also observed, and it was around 75 years, most of them had a history of surgery or cases of comorbidities before admission [34]. The reported duration of median latency of SARS infection is around 4 days and the average day to show first symptoms on hospital admission was 3.8 days, and finally, admission to death was reported around 17.4 days for casualties [35]. According to the current report, the maximum latency of SARS-CoV-2 infection is around 24 days by which the chance of infection increases. It is also observed that people around 70 years or more had shorter median days (around 11.5 days) from the first symptom to death than those with ages below 70 years (around 20 days), which indicates that elderly people are more prone than the younger one [36]. Figure 2.
Demonstrates transmission and testing procedures of suspected cases of n-COVID 19 persons.

\section{Clinical features}

- It has been observed that the Covid-19 virus produces an acute infection in people of different age groups, which has a median incubation period of 3.0 days [37].

- Clinical features of Covid-19 infection are varied from time to time, in some people, it may be an asymptomatic stage with acute respiratory distress syndrome. Some patients were also affected by multiorgan dysfunction [38].

- The most common symptom of this infection is fever, breathlessness, headache, sore 
Table 1. Treatment Strategies against n-COVID 19.

\begin{tabular}{|c|c|}
\hline Drug Treatment & Description \\
\hline $\begin{array}{l}\text { Chloroquine } \\
\text { hydroxychloroquine }\end{array}$ & $\begin{array}{l}\mathrm{CQ} \text { and HCQ both appear to have antiviral properties, either by preventing the virus } \\
\text { from attaching to the ACE2 receptors on human cells or by reducing inflammation. } \\
\text { The CQ group had a slightly larger percentage of patients who were SARS CoV2 } \\
\text { negative than the lopinavir/ritonavir groups. The use of a combination of HCQ and } \\
\text { azithromycin resulted in a considerable reduction in viral load. Certain investigations, } \\
\text { however, have found that CQ or HCQ do not improve the clinical results of COVID } 19 \\
\text { patients. The efficacy of CQ or HCQ treatment for COVID } 19 \text { is rather modest, with } \\
\text { some favourable and some negative results }[53,54] \text {. }\end{array}$ \\
\hline Ivermectin & $\begin{array}{l}\text { In an in vitro investigation, ivermectin, an FDA-approved antiparasitic medicine, was } \\
\text { effective against the SARS CoV } 2 \text { virus [55]. }\end{array}$ \\
\hline $\begin{array}{l}\text { Remdesivir and other } \\
\text { antiviral } \\
\text { analogues }\end{array}$ & $\begin{array}{l}\text { Remdesivir successfully reduced viral load in a mouse model infected with SARS CoV } \\
\text { and suppressed viral replication in primary human lung cells infected with } \\
\text { coronavirus. Remdesivir was licenced by the FDA for the emerging treatment of } \\
\text { COVID 19-infected hospitalised patients, and it was indicated for use in adult and } \\
\text { paediatric patients aged }>12 \text { years and weighing at least } 40 \mathrm{~kg} \text {. Ribavirin and } \\
\text { Galidesivir both reduced viral load and enhanced survival rates. The RdRp of RNA } \\
\text { viruses was likewise strongly suppressed by favipiravir }[56,57] \text {. }\end{array}$ \\
\hline Antibody-based therapy & $\begin{array}{l}\text { Antibodies (Abs) have long been utilised to treat viral infections by neutralising viral } \\
\text { antigens. A subgroup of the Abs may be able to stop SARS CoV } 2 \text { infection in its tracks. } \\
\text { Although the titers of neutralising Abs against SARS CoV } 2 \text { in human plasma diminish } \\
\text { over time, these Abs can last for at least three months in the human body. SARS CoV } \\
\text { is combated using CR3022, a neutralising mAb. Most of these Abs have shown } \\
\text { antiviral activity in preclinical tests, and some, such as CT P59, ADG20, CB6LALA, } \\
\text { AZD8895, AZD1061 and DXP 593, are in phase } 2 \text { or } 3 \text { clinical trials against COVID 19 } \\
\text { [58]. }\end{array}$ \\
\hline $\begin{array}{l}\text { Convalescent } \quad \text { Plasma } \\
\text { Therapy }\end{array}$ & $\begin{array}{l}\text { Infected patients with SARS-CoV-2 had their viral load reduced by convalescent } \\
\text { plasma therapy, which included monoclonal antibody treatment [59]. }\end{array}$ \\
\hline Immunomodulators & $\begin{array}{l}\text { Dexamethasone is strongly suggested for COVID } 19 \text { patients who require oxygen } \\
\text { delivery in the hospital. SARS-COV treatment with interferon or ribavirin alone was less } \\
\text { successful than treatment with Interferon with a high dosage of corticosteroids [60]. }\end{array}$ \\
\hline Anti-inflammatory Drugs & $\begin{array}{l}\text { Anti-inflammatory drugs such as corticosteroids, cytokines, and drugs that interfere } \\
\text { with cytokine activities (such as tocilizumab and sarilumab to block IL } 6 \text { activity, } \\
\text { infliximab and adalimumab to block TNF, and/or baricitinib and ruxolitinib as JAK1/2 } \\
\text { signalling pathway inhibitors) have been used in several clinical trials. Corticosteroids } \\
\text { were found to be effective in the treatment of patients with severe COVID } 19 \text {. As an IL } \\
1 \text { receptor antagonist, Anakinra could be a promising treatment option. Anakinra is } \\
\text { often used to treat rheumatologic disorders because it inhibits the action of the pro- } \\
\text { inflammatory cytokines IL } 1 \text { and IL } 1 \text { [61]. }\end{array}$ \\
\hline $\begin{array}{l}\text { Chinese Hebal Medicines } \\
(\mathrm{CHM})\end{array}$ & $\begin{array}{l}\text { Glycyrrhizin, a major component of the Chinese herb liquorice root (Glycyrrhiza } \\
\text { uralensis), inhibited the replication of clinically isolated SARS CoV. emodin from the } \\
\text { genus Rheumand polygonum, baicalin from Scutellaria baicalensis, scutellarin from } \\
\text { Erigeron breviscapus, tetra O galloyl D glucose from Galla chin SARS CoV was } \\
\text { inhibited by Lonicerae Japonicae Flos and Mori Folium. Antiviral activity of } \\
\text { Scutellariae radix, the root of Scutellaria baicalensis, was investigated against SARS } \\
\text { CoV2. By interfering with a critical protease, the ethanolic extract of Scutellaria } \\
\text { baicalensis reduced SARS CoV2 replication. Scutellaria baicalensis ethanolic extract } \\
\text { suppressed SARS CoV2 replication by interfering with a critical protease. Because } \\
\text { CHM contains millions of natural chemicals, screening for herbs that are effective } \\
\text { against SARS CoV } 2 \text { is time consuming. Experimental and clinical investigations are } \\
\text { still needed to confirm these expected herbs' antiviral activities against COVID } 19 \text { [62]. }\end{array}$ \\
\hline Biomolecules & $\begin{array}{l}\text { To target the host cells, usually alveolar epithelial cells, SARS-COV-2 interacts to the } \\
\text { ACE2 receptor. The ACE2 receptor is strongly attracted to the spike protein. The } \\
\text { soluble form of ACE2 could be a potential COVID-19 treatment [63]. }\end{array}$ \\
\hline
\end{tabular}

throat, cough, and fatigue, sometimes myalgia [38].

- In some patients, conjunctivitis has also been reported [38].

Early symptoms of this infection were pneumonia or respiratory failure and death in some patients, but later on, other symptoms also have been seen as an ultimate rise in inflammatory cytokines [38].

- Patients with Covid 19 showed a lower oxygenation index compared to bacterial pneumonia. 
- $\quad$ Cytokine release syndrome is a major step that enhances the progression of the disease. Higher levels of interleukin- 6 and interleukin-10 and lower levels of CD4+T and $C D 8+T$ cells are observed in Covid-19 patients, which affect the severity of the infection [39].

\section{Symptoms}

Some observed symptoms are as follows-

- Fever (around 87.9\%), cough (around 67.7\%), fatigue (around 38.1\%), whereas diarrhea $(3.7 \%)$ and vomiting $(5.0 \%)$ were found rare. These all symptoms were similar to others coronaviruses [40].

- Most of the patients have also been observed asymptomatic (without any

- $\quad$ symptoms) or mild symptoms of respiratory tract infection.

- Symptoms that have also been observed in Covid-19 patients are headache, hemoptysis, shortness of breath, decreased lymphocytes on complete blood count [41].

- Researchers also found ocular surface infection in Covid-19 patients.

- $\quad$ SARS-CoV-2 RNA was also identified in eye secretion of Covid-19 patients [42].

- Symptoms like acute heart injury, arrhythmia, impaired renal function, and abnormal liver function were also reported in some patients at the time of admission [43].

- An increased prevalence of neurological signs such as encephalopathy and encephalomyelitis, ischemic stroke and intracerebral hemorrhage, anosmia, and neuromuscular disorders may be linked to SARS-CoV-2 infection.

\section{Comorbidities}

When compared to people without comorbidities, patients with comorbidities have worse results. COVID-19 patients with a history of hypertension, obesity, chronic lung disease, diabetes, or cardiovascular disease had the worst prognosis and are more likely to develop ARDS or pneumonia. Furthermore, elderly patients in long-term care institutions, patients with chronic kidney illness, and cancer patients are not only at danger of catching the virus, but they also have a considerably higher chance of dying.

\section{Incubation period}

The incubation period is the time between infecting with the virus and the starting of the symptoms of the disease. According to the study of many researchers, the incubation period of Covid-19 disease is from 1 to14 days or most commonly around the fifth day of infection [44].

\section{Infection}

Infection is rapidly transmitted from person to person, but in children, infants, and neonates, it is reported to be significantly slower than the younger ones. The research was done in a group of 34 children (20 females and 14 males) admitted to a hospital in China for 20 days, i.e, between 19th January 2020 to 7th February 2020. The average age of the members of each group was 8 years and 11 months. The study showed that 28 children of the group had an infection because of a connection to any infected member of the family and 26 children had an infection because of travel history to Hubei province in China. All patients were also observed either asymptomatic ( around 9\%) or had a mild infection. There were no severe or critical cases were identified. One of the most common symptoms, fever, and cough, was investigated. Most of the patients recovered with symptomatic therapy without any death [45].

\section{Diagnosis}

Two types of cases are there, the first one is a suspect case and another is a confirmed case, a suspect case is that case which shows some symptoms like cough, fever, and sore throat including a travel history to China or being in contact with patients of confirmed Covid-19 infection. A confirmed case is that case which was initially a suspect case but later on, it found a positive molecular test by specific diagnosis on respiratory samples such as sputum sample, sample through throat swab, endotracheal aspirates, nasopharyngeal swab. Studies were also done on stool and blood samples and the virus was also detected in that sample [46]. In India, various reference laboratories are organized for dealing with suspect cases where the sample has to be sent for diagnosis. One of the famous laboratories is the National Institute of Virology in Pune [47]. Diagnosis can be done by the following procedure [48]

- Collect the blood samples of infected people just before providing antimicrobial treatment for bacteria that cause pneumonia.

- Antimicrobial therapy should not be delayed to collect the blood samples.

- Then start to collect a sample of nasopharyngeal and oropharyngeal swabs for a reverse transcription-polymerase chain reaction. 
- Samples from Lower Respiratory Tract should also be collected if the patient is mechanically ventilated.

- Special precautions should be taken while collecting samples from the infected persons.

- Use only sterile cloths like rayon at the time of collecting samples from the upper respiratory tract.

- Try to avoid taking the sample from the nasal route.

- If the patient has symptoms of Covid-19 like high fever and pneumonia, a single URT sample is not sufficient, try to take additional URT and LRIT samples for accurate results.

- $\quad$ Sputum induction should be avoided as it spreads infection through aerosol transmission.

\section{Treatment}

The COVID-19 outbreak generated by the severe acute respiratory syndrome coronavirus 2 (SARSCoV-2) continues to spread over the world. The current situation has highlighted the need for therapeutic options to help relieve and overcome this latest epidemic. Despite the fact that COVID-19 is worsening, no medicine has been certified to have significant impacts on the medical treatment of COVID-19 patients [49]. The pandemic of COVID-19 necessitates the quick testing of new therapeutic options. According to the data, hydroxychloroquine is the first drug used to treat disease. The antiviral agents umifenovir, remdesivir, and fevipiravir are thought to be the most promising in terms of improving the health of infected people. The antiviral agents umifenovir, remdesivir, and fevipiravir are thought to be the most promising in terms of improving the health of infected people[50]. Dexamethasone is the first known steroid drug to save the lives of very ill patients, and it was proved in a randomized clinical trial in COVID19 patients that it lowered death rates. The current study summarises the existing data of prospective therapeutic medicines, peptides, humanized antibodies, convulsant plasma, and immunization in combating COVID-19 infections. Many randomized and controlled clinical trials are being conducted to better validate the safety and efficacy of these agents in the treatment of COVID-19. Table 1 summarizes the various treatment strategies for $n$ CIVID-19 disease [51, 52].

\section{COVID-19 Vaccines}

The first large-scale immunization campaign began in early December 2020. Based on all available facts on safety and efficacy, as well as its applicability in low- and middle-income countries, the WHO Emergency Use Listing (EUL) procedure assesses whether a product can be recommended for use. Vaccines are evaluated utilizing clinical trial data, manufacturing, and quality control methods to ensure they satisfy acceptable quality, safety, and efficacy requirements. The threat posed by the emergency is weighed against the benefit that would result from using the product, as well as any potential concerns. Countries have the authority to give emergency use authorizations for any health product in accordance with their national norms and legislation. Authorizations for domestic emergency use are granted on a case-by-case basis. Vaccines for Covid-19 were produced utilizing science that has been around for a long time. These vaccines aren't being tested. They've gone through every stage of research and development for a new scientific breakthrough. Furthermore, due to the worldwide devastation that the Covid-19 virus has wreaked, many health agencies are constantly monitoring specific Covid-19 immunizations. As a result, it is critical for every citizen to participate in vaccination programs established by their local government and other organizations that provide the vaccine on a formal basis.

\section{Prevention [71]}

- Wash your hands frequently for a minimum of 20 seconds, either by shop and water or sanitized by using any sanitizer (which contain at least $60 \%$ alcohol), or hand sanitizer after using the toilet, after handling pets or their waste, before and after cooking, before eating anything, after sneezing or coughing and finally, wash your hands frequently as possible when you are sick or caring for the sick.

- Always keep your mouth and nose covered with any mask or your elbow. If you want to sneeze or cough, use tissue paper if possible and dispose of the tissue immediately in a closed bin.

- $\quad$ Try to avoid touching your eyes, nose, and mouth with your hands as they have mucous membranes that can act as pathways for the movement of infectious particles.

- Avoid direct contact with people that sneeze or cough.

- Try to maintain a social distance of about 6 feet, that is, how far the particles can travel between you and them.

- $\quad$ Teach your kids about these symptoms to recognize the patient and act accordingly.

- Stay away from crowded places.

- Avoid contact with people if you are experiencing these symptoms.

- Frequently wipe your phone, especially the screen with an alcohol-based disinfectant. 
Table 2. n-COVID 19 Vaccine under various phases of clinical trial [64-76].

\begin{tabular}{|c|c|c|c|c|}
\hline Vaccine Name & $\begin{array}{l}\text { Vaccine } \\
\text { major } \\
\text { component }\end{array}$ & Developer & EUL & $\begin{array}{l}\text { Clinical } \\
\text { Trial } \\
\text { Phase }\end{array}$ \\
\hline BNT162b2 & $\begin{array}{l}\text { mRNA } \\
\text { vaccine }\end{array}$ & Pfizer BioNTech & $\begin{array}{l}31 \\
\text { December } \\
2020\end{array}$ & $\begin{array}{l}\text { Phase I } \\
\text { to III }\end{array}$ \\
\hline BNT162b1 & $\begin{array}{l}\text { mRNA } \\
\text { vaccine }\end{array}$ & Fusun Pharma & --- & $\begin{array}{l}\text { Phase I } \\
\text { to III }\end{array}$ \\
\hline ChAdOx1-S & $\begin{array}{l}\text { Recombinant } \\
\text { Vaccine }\end{array}$ & $\begin{array}{l}\text { The } \\
\text { Oxford/AstraZeneca }\end{array}$ & $\begin{array}{l}16 \\
\text { February } \\
2021\end{array}$ & $\begin{array}{l}\text { Phase I } \\
\text { to III }\end{array}$ \\
\hline Ad26.COV2.S & $\begin{array}{l}\text { Adenovirus } \\
\text { vector }\end{array}$ & $\begin{array}{l}\text { The Johnson \& } \\
\text { Johnson }\end{array}$ & $\begin{array}{l}12 \text { March } \\
2021\end{array}$ & $\begin{array}{l}\text { Phase I } \\
\text { to III }\end{array}$ \\
\hline mRNA-1273 & mRNA & The Moderna & $\begin{array}{ll}30 & \text { April } \\
2021 & \end{array}$ & $\begin{array}{l}\text { Phase I } \\
\text { to III }\end{array}$ \\
\hline Ad5-nCoV & $\begin{array}{l}\text { Adenovirus } \\
\text { Non } \\
\text { replicating }\end{array}$ & The Sinopharm & $\begin{array}{ll}7 & \text { May } \\
2021 & \end{array}$ & $\begin{array}{l}\text { Phase I } \\
\text { and II }\end{array}$ \\
\hline PiCoVacc & $\begin{array}{l}\text { Inactivated } \\
\text { SARSCoV-2 }\end{array}$ & The Sinovac Biotech & $\begin{array}{ll}1 & \text { June } \\
2021 & \end{array}$ & $\begin{array}{l}\text { Phase I } \\
\text { to III }\end{array}$ \\
\hline $\begin{array}{l}\text { BBV152 } \\
\text { COVAXIN }\end{array}$ & $\begin{array}{l}\text { Whole virion } \\
\text { inactivated }\end{array}$ & The Bharat Biotech & $\begin{array}{l}3 \\
\text { November } \\
2021\end{array}$ & $\begin{array}{l}\text { Phase I } \\
\text { to III }\end{array}$ \\
\hline $\begin{array}{l}\text { Gam-COVID- } \\
\text { Vac }\end{array}$ & $\begin{array}{l}\text { Adenovirus } \\
\text { vector, non- } \\
\text { replicating }\end{array}$ & $\begin{array}{l}\text { Health Ministry of the } \\
\text { Russian Federation }\end{array}$ & --- & $\begin{array}{l}\text { Phase I } \\
\text { to III }\end{array}$ \\
\hline $\begin{array}{l}\text { COVID-19 } \\
\text { vaccine }\end{array}$ & $\begin{array}{l}\text { Inactivated } \\
\text { SARSCoV-2 }\end{array}$ & $\begin{array}{l}\text { Sinopharm, Wuhan } \\
\text { Institute of Biological } \\
\text { Products Co. Ltd }\end{array}$ & --- & $\begin{array}{l}\text { Phase I } \\
\text { to III }\end{array}$ \\
\hline BBIBP-CorV & $\begin{array}{l}\text { Inactivated } \\
\text { SARSCoV-2 }\end{array}$ & $\begin{array}{l}\text { Sinopharm, Beijing } \\
\text { Institute of Biological } \\
\text { Products Co. Ltd }\end{array}$ & --- & $\begin{array}{l}\text { Phase I } \\
\text { to III }\end{array}$ \\
\hline SCB-2019 & $\begin{array}{l}\text { Protein } \\
\text { subunit }\end{array}$ & $\begin{array}{l}\text { Clover } \\
\text { Pharmaceuticals, } \\
\text { GlaxoSmithKline, } \\
\text { Dynavax }\end{array}$ & $\overline{---}$ & Phase I \\
\hline NVX-CoV2373 & $\begin{array}{l}\text { Protein } \\
\text { subunit }\end{array}$ & Novavax & $\begin{array}{l}17 \\
\text { December } \\
2021\end{array}$ & Phase I \\
\hline
\end{tabular}

- Additionally, try to maintain your children's smart devices as clean as possible.

- Don't spit in a public place as it can spread harmful particles. Do it in a tissue that you can safely dispose of.

- If you are sick, stay at home as much as possible for caring for others. It decreases the viral load and the risk of spreading, and it's making your community a safer space for others.

\section{Conclusion}

The covid-19 outbreak has challenged the economy, medical, and public health infrastructure of many countries including India. As per the latest government data, Covid-19 has affected over 562 people in the country. Indian government and doctors with paramedical staff are working to the best of their services. Govt has announced a complete lockdown in the country that prevents people from leaving a given area, but citizens should understand their responsibility positively that it is not for the benefits of others or Govt. it is for their selves and their families. People of the country should follow and adhere to Government advisories strictly. Indians should take lessons from China and Italy that what havoc this novel virus can create. The need of the hour is social distancing. What goes 
through the future of COVID-19 in India is not known but one thing is for sure if we follow social distancing protocol and advisories strictly, we can make way for the lives of ours and our dear ones and can prevent the coming cyclone from hovering over India right now.

\section{Contribution of authors}

Seema Mahor developed the theoretical Concept of manuscript. Sudhanshu Mishra, Hina Chadha, Sarita Prajapati and Smriti Ojha equally contributed to the final version of the manuscript. All authors provided critical feedback and helped shape the review, analysis and manuscript.

\section{Acknowledgments}

The author declared deep thanks to the Vishveshwarya Group of Institutions, G.B.Nagar, Greater Noida.

\section{Conflict of interest}

The authors declared no conflict of interest.

\section{References}

1. Wang C, Horby PW, Hayden FG, Gao GF. A novel coronavirus outbreak of global health concern. Lancet. 2020;714-20.

2. Su. S, Wong G, Shi W, Epidemiology, genetic recombination, and pathogenesis of coronaviruses. Trends Microbiology 2016.

3. Carlos WG, Dela Cruz CS, Cao B, Pasnick S, Jamil S. Novel Wuhan (2019- nCoV) coronavirus. An J Respir Crit Care Med, 2020; 201-207.

4. World health organizations. Novel coronavirus-China. 2020. Accessed january 16, $2020 \mathrm{https} / / / w w w . w h o . i n t / c s r / d o n / 12-$ january-2020 novel coronavirus china/en/.

5. Wuhan coronavirus (2019 nCov) global cases.

2020.

https://gisanddata.maps.arcgis.co

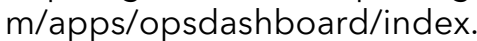

6. WHO Coronavirus disease (Covid 2019) situation reports (2020). https://www.who.int/emergencies/diseases /novel-coronavirus-2019/situation-reports.

7. WHO Virtual press conference on COVID 19. https://www.who.int/docs/default sourc e/coronaviruse/transcripts/who-audioemergencies-coronavirus-pressconference-full- and-final-11mar 2020.

8. Wu Z, Mc Googan JM. Characteristics of and important lessons from the corona virus disease 2019 (COVID 19) outbreak in China: summary of a report of 72314 case from the Chinese Centre for Disease Control and Prevention. JAMA 2020.

9. WHO Report of the WHO China Joint Mission on Coronavirus Disease 2019 (COVID

https://www.who.int/docs/defaultsource/coronaviruse/who-china-jointmission- on-covid-19.

10. Lu H, Stratton CW, Tang YW. Outbreak of pneumonia of unknown etiology in Wuhan China, the mystery and the miracle. J Med Virol.2020; 92:401-402. 10.1002/jmv.25678

11. Richman DD, Whitley RJ, Hayden FG. Clinical Virology, 4th edition. Washington, ASM Press; 2016.

12. Du Toit, An outbreak of a novel coronavirus. Nat Rev Microbiol. 2020; 18:123. 10.1038/s41579-020-0332-0

13. ChanYeung $M, X u R H, S A R S$ : epidemiology. Respirology. 2003;8:S9-14.

14. Mishra S, Sharma D, Raghuvanshi A, Rajput A, Chaturvedi V, Shanno K. Potential Impact of Nutrition on Immune System: Prevent or Assist COVID-19 Recovery. Journal of Advances in Medicine and Medical Research. 2020;23:20-33.

15. Huang $C$, Wang Y, Li X, Ren L, Zhao J, Hu Y. Clinical features of patients in- fected with 2019 novel corona virus in Wuhan, China. Lancet (London, England). 2020; 395:497506.

16. Liu, Y., Gayle, AA. Wilder Smith, A., Rocklov, $J$. The reproductive number of Covid- 19 is higher compared to SARS corona virus. J Travel Med. 2020.

17. Singh Tanu. A review on corona virus disease-2019 (Covid -9). The Ind J paediatric, 2020;87: 281-286.

18. Seyed Alinaghi S, Mirzapour P, Dadras O. et al. Characterization of SARS-CoV-2 different variants and related morbidity and mortality: a systematic review. Eur J Med Res. 2021; 26: 51.

19. Poterico JA, Mestanza O. Genetic variants and source of introduction of SARS-CoV-2 in South America. J Med Virol. 2020;10:213945.

20. Parlikar A, Kalia K, Sinha S, Patnaik S, Sharma $\mathrm{N}$, Vemuri SG, et al. Understanding genomic diversity, pan-genome, and evolution of SARS-CoV-2. Peer J. 2020;8:e9576.

21. Pachetti M, Marini B, Benedetti F, Giudici F, Mauro E, Storici $P$, et al. Emerging SARSCoV-2 mutation hot spots include a novel RNA-dependent-RNA polymerase variant. J Transl Med. 2020;18:1-9.

22. Mukherjee M, Goswami S. Global cataloguing of variations in untranslated regions of viral genome and prediction of key host RNA binding protein-microRNA 
interactions modulating genome stability in SARS-CoV-2. PLoS ONE. 2020;15(8):e0237559.

23. Muhammad Ansori AN, Dhea Kharisma $V$, Sabilil Muttaqin S, Antonius Y, Parikesit AA. Genetic variant of SARS-CoV-2 isolates in Indonesia: spike glycoprotein gene. J Pure Appl Microbiol. 2020;14(1):971-8.

24. Lokman SM, Rasheduzzaman M, Salauddin A, Barua R, Tanzina AY, Rumi MH, et al. Exploring the genomic and proteomic variations of SARS-CoV-2 spike glycoprotein a computational biology approach. Infect Genet Evol. 2020;84:104389.

25. Lau S-Y, Wang P, Mok BW-Y, Zhang AJ, Chu $\mathrm{H}$, Lee AC-Y, et al. Attenuated SARS-CoV-2 variants with deletions at the S1/S2 junction. Emerg Microb Infect. 2020;9(1):837-42.

26. Kozlovskaya L, Piniaeva A, Ignatyev G, Selivanov A, Shishova A, Kovpak A, et al. Isolation and phylogenetic analysis of SARSCoV-2 variants collected in Russia during the COVID-19 outbreak. Int J Infect Dis. 2020;99:40-6.

27. Koyama $T$, Platt $D$, Parida L. Variant analysis of SARS-CoV-2 genomes. Bull World Health Organ. 2020;98(7):495.

28. Bassetti, M., Vena, A., Giacobbe, DR., The novel Chinese coronavirus (2019 nCoV) infections, challenges for fighting the storm. Eur J Clin Invest. 50:e13209. 10.1111/eci.13209

29. Mishra Sudhanshu, Sharma Disha, Srivastava Prakash Shobhit, Verma Swati and Malviya Rishabha, Impact on Pharmaceutical Industry due to Sudden Pandemic Attack (COVID-19), Coronaviruses 2022; 3.

30. Ji W, Wang W, Zhao X, Zai J, Li X. Homologous recombination within the spike glycoprotein of the newly identified corona virus may boost cross-species transmission from snake to human. Journal of medical virology.2020.

31. Zhang $C$, Zheng W, Huang $X$, Bell EW, Zhou $X$, Zhang Y. Protein structure and sequence re-analysis of 2019-nCoV genome does not indicate snakes as its intermediate host or the unique similarity between its spike protein insertions and HIV 2020, 1.02.04.933135

32. Wang J, Zhao S, Liu M, Zhao Z, Xu Y, Wang, P. ACE2 expression by colonic epithelial cells is associated with viral infection, immunity and energy metabolism. 2020: 02.05.20020545.

33. Xiao F, Tang M, Zheng X, Li C, He J, Hong Z. Evidence for gastrointesti- nal infection of SARS CoV 2.medRxiv.2020: 02.17.2002372.

34. Cho SY, Kang JM, Ha YE, Park GE, Lee JY, Ko $\mathrm{JH}$, MERS-CoV outbreak following a single patient exposure in an emergency room in South Korea, an epidemi ological outbreak study. Lancet 2016; 388:994-1001.

35. Lessler J, Reich NG, Brookmeyer R, Perl TM, Nelson KE, Cummings DA. Incu- bation periods of acute respiratory viral infections: a systematic review. The Lancet Infectious diseases. 2009; 9:291-300.

36. Wang W, Tang J, Wei F. Updated understanding of the outbreak of 2019 novel Corona virus (2019-nCoV) in Wuhan, China. Journal of medical virology.2020: 92:441-7.

37. Guan W J, Ni ZY, Hu Y, Liang WH. Clinical characteristics of 2019 novel corona virus infection in China.2020; 02.06.20020974.

38. Chen N, Zhou M, Dong X. Epidemiological and clinical characteristics of 99 cases of 2019 novel coronavirus pneumonia in Wuhan, China: a descriptive study. Lancet. 2020; 395:507-13.

39. Wan S, Yi Q, Fan S, Lv J, Zhang X, Guo L, Characteristics of lymphocyte sub- sets and cytokines in peripheral blood of 123 hospitalized patients with 2019 novel corona virus pneumonia (NCP). Med Rxiv.2020; 02.10.20021832.

40. Sinha, A., One COVID-19 positive infects 1.7 in India, lower than in hot zones. The Indian Express, 23 March 2020.

41. Ren LL, Wang YM, Wu ZQ. Identification of a novel coronavirus causing severe pneumonia in human, a descriptive study. Chin Med J. 2020; 10.1097/CM9.

42. Ai T, Yang Z, Hou H, Zhan C, Chen C, Lv W. Correlation of Chest CT and RT-PCR Testing in Corona virus Disease 2019 (Covid-19) in China. A Report of 1014 Cases. Radiology.2020; 200642

43. Li Z, Wu M, Guo J, Yao J, Liao X, Song S. Caution on Kidney Dysfunctions of 2019nCoV Patients. 2020

44. Sharma K, Mishra S, Gautam A, Malviya R. Mucormycosis-a Fungal Infection in Patient Recovered from COVID-19.

45. Zeng LK, Tao XW, Yuan WH, Wang J, Liu X, Liu ZS. First case of neonate infected with novel coronavirus pneumonia in China. Zhonghua Er Ke Za Zhi. 2020; 58:E009.

46. PRC NH Cot, The Novel Corona virus Pneumonia Diagnosis and Treatment Plan 2020.

47. Huang P, Liu T, Huang L. Use of chest CT in combination with negative RT-PCR assay for the 2019 novel coronavirus but high clinical suspicion. Radiology. 2020; https://doi.org/10.1148/radiol.2020200330

48. Guidelines on Clinical Management of Covid 19. Available from: 
https://www.mohfw.go v.in/pdf/Guidelines on Clinical Management of Covid- 19.

49. Lu H, Drug treatment options for the 2019, new coronavirus (2019-nCoV). Biosci Trends. 2020; 14:69-71. 10.5582/bst.2020.01020.

50. Shalhoub S, Farahat F, Al-Jiffri A, et al. IFN$\alpha 2 a$ or IFN- $\beta 1$ a in combination with ribavirin to treat Middle East respiratory syndrome coronavirus pneumonia: a retrospective study. J Antimicrob Chemother 2015; 70(7): 2129-3.

51. Sheahan TP, Sims AC, Graham RL, et al. Broad-spectrum antiviral GS-5734 inhibits both epidemic and zoonotic coronaviruses. Sci Transl Med 2017; 9: eaal3653.

52. Saijo M, Morikawa S, Fukushi $S$, et al. Inhibitory effect of mizoribine and ribavirin on the replication of severe acute respiratory syndrome (SARS)-associated coronavirus. Antiviral Res 2005; 66(2-3): 159-63.

53. Peters $H L$, Jochmans $D$, de Wilde $A H$, et al. Design, synthesis and evaluation of a series of acyclic fleximer nucleoside analogues with anti-coronavirus activity. Bioorg Med Chem Lett 2015; 25(15): 2923-6.

54. Shoemaker CJ, Schornberg KL, Delos SE, et al. Multiple cationic amphiphiles induce a Niemann-Pick $C$ phenotype and inhibit Ebola virus entry and infection. PLoS One 2013; 8(2): e56265.

55. Bleibtreu A, Jaureguiberry $S$, Houhou N, et al. Clinical management of respiratory syndrome in patients hospitalized for suspected Middle East respiratory syndrome coronavirus infection in the Paris area from 2013 to 2016. BMC Infect Dis 2018; 18(1): 331-40.

56. Al-Abdely HM, Midgley CM, Alkhamis AM, et al. Middle East respiratory syndrome coronavirus infection dynamics and antibody responses among clinically diverse patients, Saudi Arabia. Emerg Infect Dis 2019; 25(4): 753-66.

57. Saeed AA, Abedi GR, Alzahrani AG, et al. Surveillance and testing for Middle East respiratory syndrome coronavirus, Saudi Arabia, April 2015- February 2016. Emerg Infect Dis 2017; 23(4): 682-5.

58. Jin YH, Cai L, Cheng ZS, et al. A rapid advice guideline for the diagnosis and treatment of 2019 novel coronavirus (2019-nCoV) infected pneumonia (standard version). Mil Med Res 2020; 7(1): 4-26.

59. Dayer MR, Taleb-Gassabi S, Dayer MS. Lopinavir; a potent drug against coronavirus infection: insight from molecular docking study. Arch Clin Infect Dis 2017; 12: e1382330.
60. Ojha S, Chadha H and Jain S, COVID-19: Pathogenesis and Pharmacological Basis for Use of Passive Antibody Therapy, Current Drug Therapy. 2020;15 (5), 448-456.

61. Holshue ML, De Bolt C, Lindquist S, Lofy KH, Wiesman J, Bruce H. First Case of 2019 Novel Corona virus in the United States. The New Eng J Med. 2020.

62. Wang M, Cao R, Zhang L, Yang X, Liu J, Xu $M$. Remdesivir and Chloroquine effectively inhibit the recently emerged novel corona virus (2019-nCoV) in vitro. Cell Res.2020.

63. Boriskin YS, Leneva IA, Pecheur El, Polyak SJ. Arbidol: a broad-spectrum antivi- ral compound that blocks viral fusion. Curr Med Chem.12008: 5:997-1005.

64. Polack FP. Safety and efficacy of the BNT162b2 mRNA Covid-19 vaccine. N. Engl. J. Med. 2020;383, 2603-2615.

65. Baden LR. Efficacy and safety of the mRNA1273 SARS-CoV-2 vaccine. N. Engl. J. Med. 2021;384: 403-416 (2021).

66. Kirby J. Israel outpaced the world in vaccinations. Now it's seeing the results. Vox (2021).

https://www.vox.com/22262509/israelcovid-19-vaccinations serious-illnessdecline. 109

67. Castells MC \& Phillips EJ. Maintaining safety with SARS-CoV-2 vaccines. N. Engl. J. Med. 2020;384, 643-649.

68. Jeyanathan M. Immunological considerations for COVID-19 vaccine strategies. Nat. Rev. Immunol.2020; 20, 615-632.

69. Voysey M. Safety and efficacy of the ChAdOx1 nCoV-19 vaccine (AZD1222) against SARS-CoV-2: an interim analysis of four randomised controlled trials in Brazil, South Africa, and the UK. Lancet.2021; 397, 99-111.

70. Zhu FC. Safety, tolerability, and immunogenicity of a recombinant adenovirus type-5 vectored COVID-19 vaccine: a dose-escalation, open-label, nonrandomised, first-in-human trial. Lancet. 2020;395, 1845-1854.

71. Chen N, Zhou M, Dong X. Epidemiological and clinical characteristics of 99 cases of 2019 novel coronavirus pneumonia in Wuhan, China: a descriptive study. Lancet. 2020; 395:507-513. 10.1016/S01406736(20)30211-7.

72. Cao B, Wang Y, Wen DA. Trial of lopinavirritonavir in adults hospitalized with severe Covid-19, N Engl J Med. 2020;10.1056/NEJMoa2001282.

73. Loutfy MR, Blatt LM, Siminovitch KA, Ward S, Wolff B, Lho H. Interferonal- facon-1 plus corticosteroids in severe acute respiratory 
syndrome: a preliminary study. Jama.2013; 290:3222-8.

74. Gilardin L, Bayry J, Kaveri SV. Intravenous immunoglobulin as clinical immunemodulating therapy. Cmaj. 2015; 187:25764.

75. Zarbock A, Kellum JA, Schmidt C, Van Aken $\mathrm{H}$, Wempe C, Pavenstadt H. Effect of Early vs. Delayed Initiation of Renal Replacement Therapy on Mortality in Critically III Patients With Acute Kidney Injury, The Elain Randomized Clinical Trial. Jama.2016.

76. Lim CC, Tan CS, Kaushik M, Tan HK. Initiating acute dialysis at earlier Acute Kidney Injury Network stage in critically ill patients without traditional indications does not improve outcome: a prospective cohort study. Nephrology Carlton.2015;20:148-54. 